\title{
Evaluating the Performance of Libyan Banks Using Return on Investment
}

\author{
Khalad M.S. Alrafadi and Mazila Md-Yusuf \\ Faculty of Business Management, Universiti Teknologi MARA (UiTM), Malaysia
}

Received 2012-03-26; Revised 2014-01-05; Accepted 2014-01-06

\begin{abstract}
Return on Investment (ROI) is a financial ratio which commonly used to evaluate the overall performance of a company. Despite of the importance of ROI unfortunately not many Libyan banks use it to evaluate their performance. Most of Libyan banks use the result of income statements to evaluate their performance instead of other tools that use to evaluate performance of banks. This study will be focusing on the ROI. The objective of this research is to evaluate the performance of Libyan banks using ROI as a financial tool. The Libyan banks which involved in this research are: Alwahda bank, National Commercial bank, Commercial and Development bank, Mediterranean bank and Alejmaa Alarabi bank. In this research financial statements of the Libyan banks for period from 2005-2009 will be used to calculate the ROI. In general, the results of the ROI of the banks used in this research showed increase and then begin to decrease and then increase again. The results clearly indicate that the performance of Libyan banks is not stable depending on components of ROI.
\end{abstract}

Keywords: Evaluating Performance, Financial Ratio, Return on Investment (ROI)

\section{INTRODUCTION}

Financial ratios are the oldest and important method for analyzing company performance. Mainly it is used to study the financial and credit position of organizations, in this method the performance is based on the examination of the financial statements. However, the number included in a financial statement does not indicate if it is important and it does not always provide useful information. The importance of the number is only when compared with other numbers (Tofeeq, 1997). Brigham and Ehrhardt (2005) state that "financial ratios are designed to help evaluate financial statements". Financial ratios are useful as a planning and control tool.

Financial ratios analysis is used to evaluate the performance of an organization. It aims to determine the strong and weak points and it offers solutions by providing appropriate plans (Zayod et al., 2005). A large number of standards and various financial ratios can be used when analyzing the credit and financial position of organizations. The choice of ratios used for analysis depends largely on the type of activity in an organization and the purpose of analysis (Tofeeq, 1997).

Most researchers divide the financial ratios into four groups (Ross et al., 2007).

Liquidity ratios this indicates an organization's ability to pay debt in the short run (Lasther, 2005) and Activity ratios Gitman et al. (2002) stated that "These are used to measure the speed with various accounts are converted into sales or cash". They are also used to measure how efficiently a company manages its assets (DUFR, 2011). After that Debt ratio these show how effectively the organization uses other people's money and whether it is using a lot of borrowed money (Lasher, 2005). The last one is Profitability ratios consist of several measures which assesses an organization's success in making money (Lasher, 2005). Profitability ratios are used to evaluate the company's ability to generate profits from its operational activities and include some ratios such as Net Profit Margin, Gross Profit, Return on Assets (ROI), Return on Equity (ROE), Corresponding Author: Khalad M.S. Alrafadi, Faculty of Business Management, Universiti Teknologi MARA (UiTM), Malaysia 
Return on Investment (ROI) and net earnings per share (Sheikh, 2009).

The nature of the organization influences the ratios employed. For example, in the case of a bank, the liquidity ratio is used to determine the amount of liquidity that a bank needs in order to meet its liabilities; a bank also uses profitability ratios (Tarawneh, 2006). Industrial organizations focus on profitability and activity ratios. On the other hand, non-profit organizations attempt to get enough financial resources to continue their activities, so they tend to focus on debt ratios.

There are limitations to use financial ratios including; financial ratios analysis measure performance in the past and cannot predict what the firm will be in the future, also financial ratios analysis ignores many factors that effect on the performance of the company such as customer satisfaction and financial ratios are affected by all the problems that appear in the financial statements because it measures the relationship between the elements of financial statements in a certain moment (DUFR, 2011).

Unfortunately not many Libyan banks use the information in the annual reports to evaluate their performance despite of the importance of ROI. So, in this study we focus on the Return on Investment (ROI) and we aim to evaluate the performance of Libyan banks as a financial ratio tool.

This study is organized as follows: First some background information about ROI and then the methodology section that discusses the sample selection and variables measured. Following that are the results and conclusion.

\subsection{Return on Investment}

Organizations may have centers which control processes done such as cost centers. These centers have control over costs which are evaluated by measuring the range of achievements of decided standard costs (Gareson and Norain, 2002). Organizations may also have profit centers that have control over all costs and revenues that are evaluated by performance reports of income statements which explain the differences between actual and estimated statements. Organizations may also add investment centers which have control over costs, revenues and use of investment money, that can be evaluated by income statements too but one usually uses the ROI which determines the comprehensive performance of an organization. When a manager has all the responsibility and authority for his or her center's working capital and physical assets, the manager is running an investment center. The performance of such a unit is best measured with a metric that relates profits earned to the level of physical and financial assets employed in the center. Investment center managers are evaluated with metrics such as the ROI and economic value added (Kaplan, 2006). For a short term, it seemed as though nearly every firm that went public was only interested in 'share holder value' in an effort to drive up the value of the stock and of course, employee held stock options. The ROI may the most important ratio of all. It is the percentage of return on funds invested in the business by its owners (FRA, 2011). The ROI can be defined as the investment's ability to achieve a return due to its use and if we want to measure the investment's ability effectively we have to compare the achievement return with returns for previous periods of the same organization or with returns for other organizations which operate in the same sector. Therefore it is necessary to express this return as a percentage of the investment used (Almaghbob, 1991). ROI reveals area where capital is being effectively employed and this information is helpful in obtaining a desired balance in the use of facilities (Terry, 1985).

There are three dominant reasons for using the ROI: First, most people can understand ROI easily. Second, it combines three critical performance measures variables scale, earnings and investment. Third, it is popular with financial analysts, investors, creditors and other external information users (ROI Vs ROS, 2011).

There are some advantages for using ROI including that the ROI focus on profits, objective to cost and profits, also readily available data, different sized divisions, it is fair to different sizes and managers accept project with higher ROI's (MADPE, 2011).

Also there are some advantages for using ROI including that the ROI is a historic measure, accounting policies, ignore risk, there are some methods better decision criteria more than ROI such as Net Present Value (NPV) and projects which have a slow payoff maybe rejected (MADPE, 2011).

\section{METERIALS AND METHODS}

\subsection{Methodology}

In this study five Libyan banks that headquarters located in Benghazi and Albida city were chosen as the sample. These banks are Alwahda was established under the law (153) dated 22/12/1970 and provides all sorts of banking products and services through (76) 
branch and agency spread over all Libya that are supplied with modern technology and hardware. National Commercial Bank was established under law (153) dated 22/12/1970 and provides all sorts of banking products and services through (64) branches spread over all Libya. Commercial and Development Bank was established according the law (1) dated in 1993. Mediterranean bank was established in 1997 under the name of Bank Al Ahli Benghazi and when the issuance of law No. (1) In 2005 and meet the requirements of the provisions of this law has change its name to Mediterranean bank and Alejmaa Alarabi bank was established based on the decision of the minister of finance No. (50) In 2003 and began its operations in August 2003. Data of this study was obtained from financial statements of these banks from 2005-2009. Also, net operating income, revenues and operating assets were also used as variables in this study.

For the purpose of this study ROI, is defined as follows.

\subsection{Revenues}

This is money which is obtained by sale goods or services. In the banking industry, this revenue is money which is obtained for the provision of mortgages, social loans, credit facilities and commercial loans. It also includes the following items: Interest earned, bank commissions, currency exchange and other miscellaneous revenues for example fines collected as a result of delays in payment of instalments for loans.

\subsection{Net Operating Income}

A net income before interests and taxes.

\subsection{Operating Assets}

Assets include cash, debtors, building, machinery and equipments and other assets. Assets that are not included as operating assets are land that is retained for use in future expansions or buildings rented to others.

In this study we calculated using the following formula Equation (1-3):

ROI $=$ Profit Margin $\mathrm{x}$ Turnover operating assets

Profit Margin $=\frac{\text { Net operating income }}{\text { Re venues }}$

Turnover operating assets $=\frac{\text { Revenues }}{\text { Operating assets }}$

\section{RESULTS}

In this study data was collected from Alwahda Bank, National Commercial Bank and Commercial and Development Bank from 2005-2009 and Table 1 below shows the data were collected.

Table 2 shows results that were calculated using Equation (1).

The purpose of the study was to evaluate the performance of Libyan banks compared to the standard performance. As there were no standards available to compare with ROI in Libyan banks, in this study we compared the performance of Libyan banks historically.

\subsection{For Alwahda Bank}

The ROI increased by $13.25 \%$ from $2005-2006$ because Profit Margin and Turnover of Assets were increased by $0.79 \%, 12.12 \%$ respectively. Then It decreased in 2007 depending on decreasing of Turnover of assets, because of increasing rate of assets was greater than increasing rate of revenues and it continued to decrease to $1.15 \%$ from $2008-2009$. In 2008 the ROI decreased due to increasing of operating income, which resulted decreasing of Profit Margin and in 2009 the ROI decreased also because the Turnover of Assets was decreased due to decreasing in Revenues with increasing in Operating Assets.

\subsection{For National Commercial Bank}

The ROI increased by $15.38 \%$ from 2005-2006 because Profit Margin and Turnover of Assets were increased by $2.16 \%, 13.04 \%$ respectively. Then it decreased in 2008 because both of Profit Margin and Turnover of Assets were decreased to $0.84 \%$. It later increased again to reach $1.21 \%$ in 2009 because the Profit Margin was increased by $44.47 \%$ and Turnover of Assets was not changed.

\subsection{For Commercial and Development Bank}

The ROI was not stable as it decreased from $2005-2006$ by $23.12 \%$, because of increasing in operating income lower than increasing in revenues. It then started to increase to reach its beak in 2008 and then it started to decrease again to $1.53 \%$ in 2009 due to the profit margin was decreased, because of the Operating Income decreased with increasing in revenues. Also, due to the turnover of assets decreased because each of revenues and operating assets were increased but the rate of increase of operating assets was greater than the rate of increase of revenues. 
Table 1. The data that used to calculate ROI by 1000 LD

\begin{tabular}{|c|c|c|c|c|c|c|c|c|c|c|c|c|c|c|c|}
\hline \multirow[b]{2}{*}{ Banks } & \multicolumn{3}{|l|}{2005} & \multicolumn{3}{|l|}{2006} & \multicolumn{3}{|l|}{2007} & \multicolumn{3}{|l|}{2008} & \multicolumn{3}{|l|}{2009} \\
\hline & $\mathrm{O} \mathrm{I}$ & $\mathrm{R}$ & T A & $\mathrm{O} \mathrm{I}$ & $\mathrm{R}$ & T A & $\mathrm{O} \mathrm{I}$ & $\mathrm{R}$ & T A & $\mathrm{O} \mathrm{I}$ & $\mathrm{R}$ & T A & O I & $\mathrm{R}$ & T A \\
\hline Alwahda bank & 42396 & 84115 & 2515191 & 51855 & 102151 & 2866483 & 64784 & 121925 & 3555021 & 58374 & 187686 & 4822407 & 90074 & 180226 & 7733232 \\
\hline $\begin{array}{l}\text { National } \\
\text { Commercial bank }\end{array}$ & 40399 & 89106 & 3879758 & 42944 & 92831 & 3632120 & 36786 & 105253 & 4420112 & 58657 & 154251 & 7056266 & 115671 & 210801 & 9492376 \\
\hline $\begin{array}{l}\text { Commercial and } \\
\text { Development bank }\end{array}$ & 15598 & 22501 & 906313 & 16310 & 39127 & 1238231 & 20906 & 38768 & 1391551 & 35659 & 70708 & 1815005 & 33412 & 80671 & 2178617 \\
\hline Mediterranean bank & 2763 & 3334 & 28048 & 1580 & 2205 & 39885 & 3800 & 5060 & 87668 & 4489 & 6353 & 102035 & 4782 & 7596 & 119881 \\
\hline Alejmaa Alarabi bank & 2708 & 3758 & 83373 & 4123 & 7472 & 147048 & 3470 & 11961 & 192144 & - & - & - & - & - & - \\
\hline
\end{tabular}

Table 2. ROI calculation (\%)

\begin{tabular}{|c|c|c|c|c|c|c|c|c|c|c|c|c|c|c|c|}
\hline & \multicolumn{3}{|c|}{ Alwahda bank } & \multicolumn{3}{|c|}{ National commercial bank } & \multicolumn{4}{|c|}{ Commercial and development bank } & \multicolumn{2}{|c|}{ Mediterranean bank } & \multicolumn{3}{|c|}{ Alejmaa alarabi bank } \\
\hline & $\begin{array}{l}\text { Profit } \\
\text { Margin }\end{array}$ & $\begin{array}{l}\text { Turnover } \\
\text { of Assets }\end{array}$ & ROI & $\begin{array}{l}\text { Profit } \\
\text { Margin }\end{array}$ & $\begin{array}{l}\text { Turnover } \\
\text { of Assets }\end{array}$ & ROI & $\begin{array}{l}\text { Profit } \\
\text { Margin }\end{array}$ & $\begin{array}{l}\text { Turnover } \\
\text { of Assets }\end{array}$ & ROI & $\begin{array}{l}\text { Profit } \\
\text { Margin }\end{array}$ & $\begin{array}{l}\text { Turnover } \\
\text { of Assets }\end{array}$ & ROI & $\begin{array}{l}\text { Profit } \\
\text { Margin }\end{array}$ & $\begin{array}{l}\text { Turnover } \\
\text { of Assets }\end{array}$ & ROI \\
\hline$\overline{2005}$ & 50.4 & 3.3 & 1.66 & 45.3 & 2.3 & 1.04 & 69.3 & 2.5 & 1.73 & 82.9 & 11.9 & 9.86 & 72.1 & 4.5 & 3.24 \\
\hline 2006 & 50.8 & 3.7 & 1.88 & 46.3 & 2.6 & 1.20 & 41.7 & 3.2 & 1.33 & 71.7 & 5.5 & 3.94 & 55.2 & 5.1 & 2.82 \\
\hline 2007 & 53.1 & 3.4 & 1.81 & 35.0 & 2.4 & 0.84 & 53.9 & 2.8 & 1.51 & 75.1 & 5.6 & 4.21 & 29.0 & 6.2 & 1.80 \\
\hline 2008 & 31.1 & 3.9 & 1.21 & 38.0 & 2.2 & 0.84 & 50.4 & 3.9 & 1.97 & 70.7 & 6.2 & 4.38 & - & - & - \\
\hline 2009 & 50.0 & 2.3 & 1.15 & 54.9 & 2.2 & 1.21 & 41.4 & 3.7 & 1.53 & 63.0 & 6.3 & 3.97 & - & - & - \\
\hline
\end{tabular}

\subsection{For Mediterranean Bank}

The ROI decreased from $9.86 \%$ in 2005 - to $3.94 \%$ in 2006 by $60 \%$ because Profit Margin and Turnover of Assets were decreased by $13.5 \%, 53.8 \%$ respectively. Then it increased in 2007 depending on increasing of Profit Margin. Then increased again to $4.38 \%$ in 2008 because the Profit Margin decreased by $5.86 \%$ but the Turnover of Assets increased by $10.71 \%$. After that ROI decreased again to $3.97 \%$ in 2009 because the Profit Margin was decreased.

\subsection{For Alejmaa Alarabi Bank}

The ROI decreased from $3.24 \%$ in 2005 to reach to the lowest rate of ROI in 2007 because of decline in Profit Margin rate was greater than the rate of increase in the Turnover of Assets.

\section{DISCUSSION}

In this study, we use only the hestorical standards because there is no any standards available in banking system of Libya to compare with ROI that we are obtained from this study. The results showed that ROI for Alwahda Bank increased by $13.25 \%$ from 20052006. It then decreased to $1.15 \%$ from $2007-2009$. For National Commercial Bank the ROI increased by $15.38 \%$ from $2005-2006$ it then decreased to $0.84 \%$ in 2008. It later increased again to reach $1.21 \%$. For Commercial and Development Bank the ROI was not stable as it decreased from 2005-2006. It then started to increase to reach its beak in 2008 and then it started to decrease again. For Mediterranean bank the ROI decreased by $60 \%$ from $2005-2006$. Then started to increase in 2007 from $4.21-4.38 \%$ in 2008 , after that decreased again to reach to $3.97 \%$ in 2009 . For Alejmaa Alarabi bank the ROI decreased from $3.24 \%$ in 2005 to $1.80 \%$ in 2007 . From the results we found that the ROI for the banks is decreased comparing between 2005 and 2009. Wu (2012) found that the ROI is more influncing factor to evaluate performance and has high value for chinese banks. There are many studies use the profitability ratios (ROI, Return on Assets (ROA) and Return on Equity (ROE)) as a deteminants to measure the efficiency and evaluate performance of banks such as Sufian (2007; 2009; 2011); Casu and Molyneux (2003); Isik and Hassan (2002); Ariff and Can (2008) and Miller and Noulas (1996) they found the profitability ratios have positive significant related with efficiencies of banks. We can apply the results that we are obtained from this study for all Libyan banks, because all Libyan banks work under the same environment conditions and all Libyan banks are totally or heavelly ownered by Central Bank of Libya (CBL).

\section{CONCLUSION}

ROI is a financial ratio which is commonly used to evaluate the performance of a company. In this study ROI was used to evaluate the performance of five Libyan banks namely Alwahda Bank, National Commercial Bank, Commercial Development Bank, Mediterranean bank and Alejmaa Alarabi bank. The data was collected from financial statements of these banks from 2005- 
2009. The results clearly indicate that the performance of Libyan banks is not stable.

In this study, we have faced standards limitition, because of that we have used only the historical standard because there is no any standards are available to use it to compare with results such as industrial standard, also this study include only five Libyan banks because we cann't collect the data from all banks because the conditions in Libya during this study.

We can sugget that future studies can use more modern approches for evaluate the performance of Libyan banks such as Balanced Scorecard (BSC), Parametric approach such as Stochastic Frontier Approach (SFA) and non-parametric approach such as Data Envelopment Analysis (DEA).

\section{REFERENCES}

Almaghbob, M., 1991. Principals of Financial Management. 1st Edn., Gharian-Faculty of Accounting Publishing, Libya.

Ariff, M. and L. Can, 2008. Cost and profit efficiency of Chinese banks: A non-parametric analysis. China Econ. Rev., 19: 260-273. DOI: 10.1016/j.chieco.2007.04.001

Brigham, E. and M. Ehrhardt, 2005. Financial Management: Theory and Practice. 11th Edn., South-Western College Pub., ISBN-10: 0324259689, pp: 1024.

Casu, B. and P. Molyneux, 2003. A comparative study of efficiency in European banking. Applied Econ., 35: 1865-1876. DOI: 10.1080/0003684032000158109

DUFR, 2011. Determinants of using financial ratios.

FRA, 2011. Financial ratio analysis.

Gareson, R.H. and E. Norain, 2002. Managerial Accounting. 1st Edn., Dar Elmereak, Saudi Arabia.

Gitman, Juchau and Flanagan, 2002. Principles of Managerial Finance. 1st Edn., Addison-Wesley, Australia.

Isik, I. and M.K. Hassan, 2002. Technical, scale and allocative efficiencies of Turkish banking industry. J. Bank. Finance, 26: 719-766. DOI: 10.1016/S0378-4266(01)00167-4

Kaplan, R.S., 2006. The Demise of cost and profit centres.
Lasher, W., 2005. Practical Financial Management. 4th Edn., Thomson South-Western, Mason, ISBN-10: 0324260768, pp: 759.

MADPE, 2011. Management Accounting-divisional performance evaluation.

Miller, S.M. and A.G. Noulas, 1996. The technical efficiency of large bank production. J. Bank. Finance, 20: 495-509. DOI: 10.1016/03784266(95)00017-8

ROI Vs ROS, 2011. Performance Evaluation for HighTechnology Companies.

Ross, S., R. Westerfield, B. Jordan, A. Mazin and F. Zainal Abidin et al., 2007. Financial Management Fundamentals in Malaysia. 1st Edn., McGraw-Hill, Malaysia.

Sheikh, F., 2009. Profit Ratios.

Sufian, F., 2007. The efficiency of Islamic banking industry in Malaysia: Foreign vs domestic banks. Humanomics, 23: 174-192. DOI: 10.1108/08288660710779399

Sufian, F., 2009. Determinants of bank efficiency during unstable macroeconomic environment: Empirical evidence from Malaysia. Res. Int. Bus. Finance, 23: 54-77. DOI: 10.1016/j.ribaf.2008.07.002

Sufian, F., 2011. Benchmarking the efficiency of the Korean banking sector: A DEA approach. Benchmark. Int. J., 8: 107-127. DOI: 10.1108/14635771111109841

Tarawneh, M., 2006. A comparison of financial performance in the banking sector: some evidence from Omani commercial banks. Int. Res. J. Finance Econ., 3: 101-112.

Terry, G., 1985. Principles of management. Irwin, Illinois.

Tofeeq, J., 1997. Principles of Financial Management. Modern University Office, Alexandria, Egypt.

$\mathrm{Wu}$, H.Y., 2012. Constructing a strategy map for banking institutions with key performance indicators of the balanced scorecard. Evaluat. Program Plann., 35: 303-320. PMID: 22410163

Zayod, L., M. Alameen and M. Almohandes, 2005. Banks evaluating performance by using financial analysis tools. 